\title{
Homocysteine: New Aspects of an Ancient Enigma
}

\author{
Rita Moretti \\ Neurology Clinic, Department of Medical, Surgical, and Health Sciences, University of Trieste, Trieste, Italy
}

An extensive amount of literature has been written on homocysteine (Hcy), a sulfur-containing amino acid, related to methionine metabolism [1], either degraded via the remethylation pathway or converted, via the transsulfuration pathway, into cysteine. Nevertheless, once more, this biochemical compound is very well represented in a laboratory, and preclinically and pathologically, but the results deriving from its correction in clinical experience are poor [2].

\section{Hcy and Biochemical Functions}

Hcy is related to the production of 5,10-methylenetetrahydrofolate, a fundamental step for the synthesis of thymidylate and purines and methionine, employing vitamin $B_{12}$ and folate as cofactors [3-6]. The S-adenosylmethionine (SAM) to S-adenosyl-L-homocysteine (SAH) ratio defines the methylation potential of a cell [7]. If Hcy is allowed to accumulate in normal conditions, it will be rapidly metabolized to $\mathrm{SAH}[8,9]$. Whenever there is a methionine deficit, Hcy can be re-methylated to form methionine, by the employment of N5,N10-methylenetetrahydrofolate [10]. If there is an adequate amount of methionine, Hcy is employed for the production of cysteine, mediated by cystathionine-beta synthase, with pyridoxine as a cofactor [10]. Therefore, the accumulation of Hcy is dangerous when it occurs in the absence of folate as a cofactor. Recent studies are generally confident with the fact that lifestyle conditions (such as smoking, alcohol

\section{KARGER}

(c) 2019 S. Karger AG, Basel

E-Mail karger@karger.com

www.karger.com/crd consumption, physical inactivity) may help the elevation of Hcy [11-15]. Genetic condition of hyperhomocysteinemia (HHcy) has been considered a significant risk and often fatal factor $[5,16]$. Undoubtedly, the methylation reactions are strongly necessary for the brain, given that SAM is the sole donor in numerous methylation reactions, involving proteins, phospholipids, and biogenic amines $[16,17]$, and for packaging of many phospholipids [18]. This way, alterations of methylation with consequent Hcy accumulation lead to many congenital neural tube and central nervous system alterations [19]. The causative factors of accumulation of Hcy in healthy adult life can be diverse, due to various genetic defects or to the defects of vitamin $B_{12}$ and folate [20]. A physiological increase of Hcy occurs in the brain (and CSF) and the plas$\mathrm{ma}$, within the aging process, and more evidently inside several neurological diseases [21].

\section{Hcy and Clinical Perspectives: Neurodegeneration}

It has been proven that Hcy could be linked to neurodegeneration; Hcy (in tight relationship with higher glycine levels in the brain) is an agonist of the endogenous glutamate receptors, NMDA receptors [22], influencing calcium influx $[16,23,24]$, as well as through a direct activation of the group I metabotropic glutamate receptors [25]. Much evidence suggests that Hcy potentiates the toxicity of Abeta 42 deposition [26-28] and increases amyloid's toxicity on the smooth vascular cells in the brain 
[29]. Moreover, HHcy upregulates presenilin 1, which promotes APP synthesis [30, 31]. Finally, Hcy is related to the phosphorylation process of tau. The protein phosphatase methyltransferase 1, whose methylation is SAMdependent, regulates the activity of the protein phosphatase methyltransferase $2 \mathrm{~A}$, which acts as a dephosphorylating system for tau protein [32-34]. Hence, the reduced methylation capacity increases the hyperphosphorylation of tau protein, determining microtubule disaggregation, their precipitation, and the deposition of the neurofibrillary tangles.

\section{Hcy and Clinical Perspectives: Inflammation and Oxidative Process}

The most fascinating, irrefutable aspect of Hcy is its pro-inflammatory and pro-oxidative role. Being that the SAM-to-SAH ratio is the expression of the methylation potential of a cell, "HHcy tends to decrease the methylation potential" [10]. Therefore, Hcy can induce a global DNA hypomethylation and suppress the transcription of cyclin A in endothelial cells; at the same time, Hcy leads to upregulation of some other genes, causing an increase in p66shc expression in endothelial cells, inducing oxidant stress $[7,10]$. It is widely accepted that Hcy leads to an induction of $\mathrm{m}$-RNA and protein expression of C-reactive protein (CRP), augmenting the NR1 subunit of NMDA receptor expression; therefore, Hcy can promote a pro-inflammatory response in vascular smooth muscle cells of small brain arteries by stimulating CRP production, usually enhanced by a combined NMDA-ROSerk1/2/p38-nfKBeta signal pathway [35]. Recently, a well-conducted study [36] demonstrated that cultured cell incubation with Hcy determined cell death at $80 \mu \mathrm{M}$ Hcy exposure after 5 days; quite impressively, cell exposure to Hcy at lower concentrations for 5 days raised to a 4.4 -fold increase in reactive oxygen species (ROS) production. Hcy leads to a general upregulation of p21 and p-16 after 5 days of Hcy incubation, inducing a reduction of $35 \%$ of pRB, checkpoint regulators of G1 cell-cycle phase. In response to the HHcy level, endothelial cells produce nitric oxide (NO) to induce the formation of Snitrose-Hcy, which acts as a protector of endothelium; however, the chronic exposure to Hcy induces a final diminishment of NO [37]. Therefore, endothelial dysfunction due to HHcy results from a disruption in the cellular integrity, leading to impaired endothelium-dependent relaxation, mainly due to a reduction in the NO bioavailability $[37,38]$, to a stimulation of muscle cells, and to the promotion of inflammatory response, testified by an increase in C-reactive protein and cysteinyl leukotrienes, associated to an increment of HMG-CoA reductase activity [38]. The activities of methionine synthase that mediate the clearance of Hcy are linked to the redox potential of the cells [39]; usually, more Hcy is converted into cysteine and glutathione. A disruption of the cystathioninebeta synthase causes altered redox homeostasis and alteration of oxidative repairing process [40]. The disruption of the redox system in vascular and neuronal cells [41] accelerates the lipid peroxidation sequel of events [41-45].

Interestingly, multiple traumatism and secondary septic status associated with a systemic inflammatory response have been associated with HHcy, and the constancy of this report is related to a poor clinical outcome [46]. Curiously, this condition is not determined by a loss of folate and $\mathrm{B}_{12}$. Therefore, it can be argued that the proinflammatory condition of these patients leads to strong activation of macrophage system cascade by Hcy, with a consequent release of ample amounts of ROS, potentiating the oxidative stress [46]. HHcy activates B lymphocytes; this process seems to determine an increase of pyruvate kinase muscle isozyme 2 (PKM-2) in B cells. PKM-2 seems to suggest the so-called metabolic accelerated initiation of atherosclerosis cascade mediated by $\mathrm{HHcy}$, in vivo and in vitro [47-49]. Cultured macrophage cells exposed to Hcy showed a memory response, probably induced by epigenetic mutations [48], which influences the expression of promoter genes regulating inflammatory response and endothelium atherogenesis. A single study demonstrated an in vitro Hcy-dependent alteration of the transcriptional repression of fibroblast growth factor 2 [50]. As written above, Hcy acts on NMDA receptors: they are not only found in neurons but also on neutrophils and macrophages. The activation of these peripheral receptors, as well as in the cerebral context, rises the cytoplasmatic calcium influx and activates a pro-inflammatory cascade, with an accumulation of ROS species [51, 52], which induces an upregulation of the nuclear factor kappa $\mathrm{B}$, considered as one of "the master regulators of the expression of inflammatory genes" [52].

\section{Hcy and Clinical Experiences}

An increasing amount of evidence showed that Hcy is associated with different kinds of cardiovascular and cerebrovascular diseases $[53,54]$. It has been reported that $\mathrm{HHcy}$ relates with stroke, promoting cerebrovascu- 
lar atherosclerosis and atherothrombosis via upregulation of matrix metalloproteinases-9 (MMP-9) expression, which takes responsibility for atherosclerotic plaque instability and even their ruptures $[55,56]$. Clinical trials and studies failed to demonstrate univocal and conclusive results, either preventing HHcy through the supplementation of vitamin $B_{12}$, folate or both in patients or a healthy population, or considering HHcy as a real target of prevention. Much criticism may be led towards the trials implemented [15].

\section{Take-Home Messages}

In a debate which lasts many decades, at the moment, the only mandatory take-home messages are:

1 Hcy cannot be considered as a definite marker of vascular risk factor or neurodegeneration.
2 Hcy can be employed as a target to prevent the increase of endothelial damage and of vascular comorbidities.

$3 \mathrm{Hcy}$ is an inflammation marker, which seems to define adverse or poor outcomes in many clinical scenarios (sepsis, stroke, hemorrhage).

4 More studies should be done, more data should be collected, and more defined prospective population studies should be implemented, in order to finally have the solution of this enigma [57].

\section{Disclosure Statement}

I declare that I have no potential conflicts of interest to disclose.

\section{Funding Sources}

The study has not received any funding.

\section{References}

1 Kelly PJ, Furie KL. Management and prevention of stroke associated with elevated homocysteine. Curr Treat Options Cardiovasc Med. 2002 Oct;4(5):363-71.

2 Moretti R, Caruso P. The Controversial Role of Homocysteine in Neurology: From Labs to Clinical Practice. Int J Mol Sci. 2019 Jan;20(1): 231.

3 Mudd SH, Cantoni GL. Activation of methionine for transmethylation. III. The methionine-activating enzyme of Bakers' yeast. J Biol Chem. 1958 Mar;231(1):481-92.

4 Mato JM, Alvarez L, Ortiz P, Pajares MA. S-adenosylmethionine synthesis: molecular mechanisms and clinical implications. Pharmacol Ther. 1997;73(3):265-80.

5 Blom HJ, Smulders Y. Overview of homocysteine and folate metabolism. With special references to cardiovascular disease and neural tube defects. J Inherit Metab Dis. 2011 Feb; 34(1):75-81.

6 Parnetti L, Bottiglieri T, Lowenthal D. Role of homocysteine in age-related vascular and non-vascular diseases. Aging (Milano). 1997 Aug;9(4):241-57.

7 Loscalzo J, Handy DE. Epigenetic modifications: basic mechanisms and role in cardiovascular disease (2013 Grover Conference series). Pulm Circ. 2014 Jun;4(2):169-74.

8 Weir DG, Keating S, Molloy A, McPartlin J, Kennedy S, Blanchflower J, et al. Methylation deficiency causes vitamin B12-associated neuropathy in the pig. J Neurochem. 1988 Dec;51(6):1949-52.

9 Surtees R, Leonard J, Austin S. Association of demyelination with deficiency of cerebrospi- nal-fluid S-adenosylmethionine in inborn errors of methyl-transfer pathway. Lancet. 1991 Dec;338(8782-8783):1550-4.

10 Harvey RA, Ferrier DR. Biochemistry, Rhyner S (ed) Lippincott's Illustrated Reviews. 5th edition Philadelphia: Wolters Kluwer Health: 2011; 264-265.

11 Pietrzik K, Brönstrup A. Vitamins B12, B6 and folate as determinants of homocysteine concentration in the healthy population. Eur J Pediatr. 1998 Apr;157(S2 Suppl 2):S135-8.

12 Huang YC, Chang SJ, Chiu YT, Chang HH, Cheng $\mathrm{CH}$. The status of plasma homocysteine and related B-vitamins in healthy young vegetarians and nonvegetarians. Eur J Nutr. 2003 Apr;42(2):84-90.

13 Kulkarni K, Richard BC. Lifestyle, homocysteine, and the metabolic syndrome. Metab Syndr Relat Disord. 2003 Jun;1(2):141-7.

14 Ansari R, Mahta A, Mallack E, Luo JJ. Hyperhomocysteinemia and neurologic disorders: a review. J Clin Neurol. 2014 Oct;10(4):281-8.

15 Price BR, Wilcock DM, Weekman EM. Hyperhomocysteinemia as a risk factor for vascular contributions to cognitive impairment and dementia. Front Aging Neurosci. 2018 Oct 31;10:350.

16 Obeid R, Herrmann W. Mechanisms of homocysteine neurotoxicity in neurodegenerative diseases with special reference to dementia. FEBS Lett. 2006 May;580(13):2994-3005.

17 Miles LM, Allen E, Mills K, Clarke R, Uauy R, Dangour AD. Vitamin B-12 status and neurologic function in older people: a cross-sectional analysis of baseline trial data from the Older People and Enhanced Neurological
Function (OPEN) study. Am J Clin Nutr. 2016 Sep;104(3):790-6.

18 Que X, Hung MY, Yeang C, Gonen A, Prohaska TA, Sun X, et al. Oxidized phospholipids are proinflammatory and proatherogenic in hypercholesterolaemic mice. Nature. 2018 Jun;558(7709):301-6.

19 Blom HJ, Smulders Y. Overview of homocysteine and folate metabolism. With special references to cardiovascular disease and neural tube defects. J Inherit Metab Dis. 2011 Feb; 34(1):75-81.

20 Smith AD, Refsum H. Homocysteine, B Vitamins, and Cognitive Impairment. Annu Rev Nutr. 2016 Jul;36(1):211-39.

21 Eto K, Asada T, Arima K, Makifuchi T, Kimura $\mathrm{H}$. Brain hydrogen sulfide is severely decreased in Alzheimer's disease. Biochem Biophys Res Commun. 2002 May;293(5):1485-8.

22 Klancnik JM, Cuénod M, Gähwiler BH, Jiang ZP, Do KQ. Release of endogenous amino acids, including homocysteic acid and cysteine sulphinic acid, from rat hippocampal slices evoked by electrical stimulation of Schaffer collateral-commissural fibres. Neuroscience. 1992 Aug;49(3):557-70.

23 Robert K, Pagès C, Ledru A, Delabar J, Caboche J, Janel N. Regulation of extracellular signal-regulated kinase by homocysteine in hippocampus. Neuroscience. 2005;133(4): 925-35.

24 Lipton SA, Kim WK, Choi YB, Kumar S, D'Emilia DM, Rayudu PV, et al. Neurotoxicity associated with dual actions of homocysteine at the N-methyl-D-aspartate receptor. Proc Natl Acad Sci USA. 1997 May;94(11):5923-8. 
25 Ziemińska E, Stafiej A, Łazarewicz JW. Role of group I metabotropic glutamate receptors and NMDA receptors in homocysteineevoked acute neurodegeneration of cultured cerebellar granule neurones. Neurochem Int. 2003 Sep-Oct;43(4-5):481-92.

26 Hasegawa T, Ukai W, Jo DG, Xu X, Mattson MP, Nakagawa M, et al. Homocysteic acid induces intraneuronal accumulation of neurotoxic Abeta42: implications for the pathogenesis of Alzheimer's disease. J Neurosci Res. 2005 Jun;80(6):869-76.

27 Morris MS. Homocysteine and Alzheimer's disease. Lancet Neurol. 2003 Jul;2(7):425-8.

28 Kruman II, Kumaravel TS, Lohani A, Pedersen WA, Cutler RG, Kruman Y, et al. Folic acid deficiency and homocysteine impair DNA repair in hippocampal neurons and sensitize them to amyloid toxicity in experimental models of Alzheimer's disease. J Neurosci. 2002 Mar;22(5):1752-62.

29 Sai X, Kawamura Y, Kokame K, Yamaguchi $\mathrm{H}$, Shiraishi H, Suzuki R, et al. Endoplasmic reticulum stress-inducible protein, Herp, enhances presenilin-mediated generation of amyloid beta-protein. J Biol Chem. 2002 Apr; 277(15):12915-20.

30 Selkoe DJ. Presenilin, Notch, and the genesis and treatment of Alzheimer's disease. Proc Natl Acad Sci USA. 2001 Sep;98(20):11039-41.

31 Scarpa S, Fuso A, D’Anselmi F, Cavallaro RA. Presenilin 1 gene silencing by $S$-adenosylmethionine: a treatment for Alzheimer disease? FEBS Lett. 2003 Apr;541(1-3):145-8.

32 Leulliot N, Quevillon-Cheruel S, Sorel I, Li de La Sierra-Gallay I, Collinet B, Graille M, et al. Structure of protein phosphatase methyltransferase 1 (PPM1), a leucine carboxyl methyltransferase involved in the regulation of protein phosphatase 2A activity. J Biol Chem. 2004 Feb;279(9):8351-8.

33 Ferreira A, Lu Q, Orecchio L, Kosik KS. Selective phosphorylation of adult tau isoforms in mature hippocampal neurons exposed to fibrillar A beta. Mol Cell Neurosci. 1997;9(3): 220-34.

34 Sontag E, Hladik C, Montgomery L, Luangpirom A, Mudrak I, Ogris E, et al. Downregulation of protein phosphatase $2 \mathrm{~A}$ carboxyl methylation and methyltransferase may contribute to Alzheimer disease pathogenesis. J Neuropathol Exp Neurol. 2004 Oct;63(10): 1080-91.

35 Pang X, Liu J, Zhao J, Mao J, Zhang X, Feng L et al. Homocysteine induces the expression of $\mathrm{C}$-reactive protein via NMDAr-ROS-MAPK-
NF- $\kappa B$ signal pathway in rat vascular smooth muscle cells. Atherosclerosis. 2014 Sep; 236(1):73-81.

36 Currò M, Gugliandolo A, Gangemi C, Risitano R, Ientile R, Caccamo D. Toxic effects of mildly elevated homocysteine concentrations in neuronal-like cells. Neurochem Res. 2014 Aug;39(8):1485-95.

37 Pushpakumar S, Kundu S, Sen U. Endothelial dysfunction: the link between homocysteine and hydrogen sulfide. Curr Med Chem. 2014; 21(32):3662-72.

38 Vallance P, Chan N. Endothelial function and nitric oxide: clinical relevance. Heart. 2001 Mar;85(3):342-50.

39 Banerjee R, Zou CG. Redox regulation and reaction mechanism of human cystathioninebeta-synthase: a PLP-dependent hemesensor protein. Arch Biochem Biophys. 2005 Jan; 433(1):144-56.

40 James SJ, Cutler P, Melnyk S, Jernigan S, Janak L, Gaylor DW, et al. Metabolic biomarkers of increased oxidative stress and impaired methylation capacity in children with autism. Am J Clin Nutr. 2004 Dec;80(6): 1611-7.

41 Perna AF, Ingrosso D, De Santo NG. Homocysteine and oxidative stress. Amino Acids. 2003 Dec;25(3-4):409-17.

42 Ignarro LJ, Buga GM, Wood KS, Byrns RE, Chaudhuri G. Endothelium-derived relaxing factor produced and released from artery and vein is nitric oxide. Proc Natl Acad Sci USA. 1987 Dec;84(24):9265-9.

43 Hoffman M. Hypothesis: hyperhomocysteinemia is an indicator of oxidant stress. Med Hypotheses. 2011 Dec;77(6):1088-93.

44 Sawle P, Foresti R, Green CJ, Motterlini R. Homocysteine attenuates endothelial haem oxygenase- 1 induction by nitric oxide (NO) and hypoxia. FEBS Lett. 2001 Nov;508(3): 403-6.

45 Stühlinger MC, Tsao PS, Her JH, Kimoto M, Balint RF, Cooke JP. Homocysteine impairs the nitric oxide synthase pathway: role of asymmetric dimethylarginine. Circulation. 2001 Nov; 104(21):2569-75.

46 Ploder M, Kurz K, Spittler A, Neurauter G, Roth E, Fuchs D. Early increase of plasma homocysteine in sepsis patients with poor outcome. Mol Med. 2010 Nov-Dec;16(11-12): 498-504.

47 Deng J, Lü S, Liu H, Liu B, Jiang C, Xu Q, et al. Homocysteine activates $B$ cells via regulating PKM-2 dependent metabolic reprogramming. J Immunol. 2017 Jan;198(1):170-83.
48 Li JJ, Li Q, Du HP, Wang YL, You SJ, Wang F, et al. Homocysteine Triggers inflammatory responses in macrophages through inhibiting CSE-H2S signaling via DNA hypermethylation of CSE promoter. Int J Mol Sci. 2015 Jun;16(6):12560-77.

49 Yi-Deng J, Tao S, Hui-Ping Z, Jian-Tuan X, Jun C, Gui-Zhong L, et al. Folate and ApoE DNA methylation induced by homocysteine in human monocytes. DNA Cell Biol. 2007 Oct;26(10):737-44.

50 Chang PY, Lu SC, Lee CM, Chen YJ, Dugan TA, Huang WH, et al. Homocysteine inhibits arterial endothelial cell growth through transcriptional downregulation of fibroblast growth factor-2 involving $G$ protein and DNA methylation. Circ Res. 2008 Apr;102(8): 933-41.

51 Boldyrev A, Bryushkova E, Mashkina A, Vladychenskaya $\mathrm{E}$. Why is homocysteine toxic for the nervous and immune systems? Curr Aging Sci. 2013 Feb;6(1):29-36.

52 Ying G, Wang Y, Cen XM, Yang M, Liang Y, Xie QB. Lipid peroxidation-mediated inflammation promotes cell apoptosis through activation of NFK-B pathway in rheumatoid arthritis synovial cells. Mediators Inflamm. 2015;2015:460310.

53 Khan U, Crossley C, Kalra L, Rudd A, Wolfe $\mathrm{CD}$, Collinson $\mathrm{P}$, et al. Homocysteine and its relationship to stroke subtypes in a UK black population: the south London ethnicity and stroke study. Stroke. 2008 Nov;39(11): 2943-9.

54 Selhub J, Bagley LC, Miller J, Rosenberg IH. B vitamins, homocysteine, and neurocognitive function in the elderly. Am J Clin Nutr. 2000 Feb;71(2):614S-20S.

55 Li Z, Sun L, Zhang H, Liao Y, Wang D, Zhao B, et al.; Multicenter Case-Control Study in China. Elevated plasma homocysteine was associated with hemorrhagic and ischemic stroke, but methylenetetrahydrofolate reductase gene C677T polymorphism was a risk factor for thrombotic stroke: a Multicenter Case-Control Study in China. Stroke. 2003 Sep;34(9):2085-90.

56 Ali Z, Troncoso JC, Fowler DR. Recurrent cerebral venous thrombosis associated with heterozygote methylenetetrahydrofolate reductase C677T mutation and sickle cell trait without homocysteinemia: an autopsy case report and review of literature. Forensic Sci Int. 2014 Sep;242:e52-5.

57 Nichols J. Testing for homocysteine in clinical practice. Nutr Health. 2017 Mar;23(1):13-5. 